\title{
Pengembangan Modul Pembelajaran Terintegrasi Keislaman Mata Kuliah Botani Tumbuhan Tinggi Materi Angiospermae Kelas Liliopsida
}

\author{
Dicka Debby Swastika \\ IAIN Palangka Raya, Jl. G Obos 11 A, Palangka Raya, 73111, Indonesia \\ *Alamat Email Koresponden: debbyswastika123@gmail.com \\ diterima: 2 Maret 2020, disetujui: 6 Maret 2020, dipublikasikan: 30 Maret 2020
}

\begin{abstract}
This study departs from field observations which state that the low student learning outcomes in 2013 that is with a percentage of $52.38 \%$ getting grades below the KKM, it needs the existence of more efficient teaching materials, to support student learning processes independently. This study aims to determine the validity, effectiveness and practicality of the Islamic integrated learning module in the High Plant Botany course for Angiosperms in Liliopsida class. This research uses the Research \& Development method which was developed using the ADDIE model with stages: Analyze the needs analysis, Design is the design / draft module, Development is product development / prototype based on design validation, design revision, small scale trial, revision I module, Implementation is application of modules in large-scale trials of control classes / without modules, and experimental classes / using modules, Evaluation ie revision II modules, final modules. The results of this study indicate that the module developed is feasible to be used in learning High Botanical Botany lectures obtained from the validity value of material experts $83.60 \%$ very good or valid, $80 \%$ good / valid design experts, $82 \%$ good / valid religious experts. The practicality of the use of the modules obtained from the observation of the implementation of learning by $91.41 \%$ was very successful and the student questionnaire responses showed $99.15 \%$ of the practical modules were used. The effectiveness of the application of the module is obtained from the increase in student learning outcomes with $N$-Gain of 0.77 in the high category compared to the control class of the value of N-Gain of 0.20 in the low category. Thus, the learning modules developed are valid, practical, and effective for use in learning.
\end{abstract}

Keywords : Angiosperms, Module, Integrated Islamic, Liliopsida. 


\section{PENDAHULUAN}

Mata kuliah Botani Tumbuhan Tinggi merupakan mata kuliah wajib yang memiliki bobot 3 sks. Sebagai salah satu mata kuliah wajib yang harus di ambil oleh mahasiswa, maka mata kuliah Botani Tumbuhan Tinggi harus memiliki bahan ajar yang baik dan memadai. Salah satu bahan ajar yang dianggap memadai dan baik digunakan untuk mahasiswa adalah modul. Modul pembelajaran disini berperan penting dalam menunjang kelangsungan belajar para mahasiswa, karena memiliki bahasa yang mudah dipahami, praktis dan lebih langsung menuju pada sasaran belajar. Hernawan, Herry, Permasih, dan Dewi (2012); Prawiradilaga dan Salma (2014); Susilana, Rudi, dan Riyana, (2008 ) menyatakan bahwa modul sangat berperan penting dalam proses pembelajaran karena modul telah disusun secara sistematis dan mampu membantu peningkatan pendidikan dengan berbagai faktor penunjang untuk mencapai tujuan pembelajaran. Pada RPS mata kuliah Botani Tumbuhan Tinggi yang telah di buat oleh dosen pengampu lebih menjabarkan materi Botani Tumbuhan Tinggi yang berkaitan langsung dengan integrasi ayat AlQur'an maupun hadist. Achjar (2009); Silviyanti (2018); Permadi (2016); dan Nurohmati (2017) menyatakan bahwa modul pembelajaran yang di lengkapi dengan integrasi keislaman di anggap baik karena memudahkan mahasiswa untuk memahami konsep pembelajaran materi yang langsung berkaitan dengan ciptaan Tuhan. Modul pembelajaran yang terintegrasi keislaman juga menambah wawasan mahasiswa mengenai ilmu sains dengan ilmu keislaman yang bersumber Al-Qur'an maupun hadits tanpa menghilangkan kedua unsur tersebut.

Lestariningsih, Mulyono dan Ayatussa'adah (2017) menyatakan dalam proses perkuliahan mahasiswa Tadris Biologi IAIN Palangka Raya khususnya mata kuliah Botani Tumbuhan Tinggi terdapat keterbatasan sarana belajar yaitu belum tersedianya buku ataupun modul yang mengaitkan sains dengan integrasi keislaman. Sedangkan dalam Rencana Perkuliahan Semester (RPS) mata kuliah Botani Tumbuhan tinggi di sebutkan bahwasannya salah mahasiswa harus mengaitkan ilmu sains atau materi Botani Tumbuhan Tinggi dengan integrasi Keislaman, dan di kaitkan dengan Kurikulum yang tercantum di Program Studi Tadris Biologi di antaranya terdiri dari visi, misi, tujuan, profil lulusan, dan kompetensi lulusan (terdiri dari 3 aspek penting yang saling berkaitan seprerti aspek materi, aspek integrasi keislaman dan aspek khasiat tumbuhan dalam pengobatan).

Berdasarkan observasi di lapangan serta pengalaman belajar mata kuliah Botani Tumbuhan Tinggi bahwasannya belum adanya referensi yang relevan sehingga materi yang didapatkan sangat sedikit. Sebagian mahasiswa juga kurang aktif dalam mencari literasi yang berbentuk elektronik seperti e-book, kurangnya kegemaran untuk membaca serta kurangnya pengetahuan dalam penggunaan media masa kini. Masih terdapat beberapa sub materi yang hanya terdapat pada artikel atau jurnal tertentu dan membuat mahasiswa merasa kesulitan untuk menemukan sumber belajar yang akurat, sehingga mengambil atau mengakses dari blok pribadi milik pengguna google yang terbilang belum relevan untuk di jadikan sumber belajar khususnya tingkat mahasiswa. Hal ini juga di kuatkan dengan hasil wawancara pada beberapa mahasiswa yang telah mengambil mata kuliah Botani Tumbuhan Tinggi (mahasiswa semester 5) menyatakan bahwa masih mengalami banyak kesulitan dalam mencari referensi mata 
kuliah Botani Tumbuhan Tinggi karena belum menggunakan modul yang membahas materi ajar secara spesifik. Saat ini, referensi yang digunakan berupa buku-buku yang terbilang sangat terbatas serta jurnal yang dianggap belum spesifik membahas 3 aspek yang akan dicapai dalam perkuliahan. Aspekaspek tersebut meliputi pembahasan materi ajar, integrasi keislaman berkaitan dengan materi ajar, serta peranan tumbuhan yang dikaji. Beberapa dari mahasiswa menganggap bahwa materi Angiospermae kelas Liliopsida merupakan salah satu materi yang terbilang sulit dan referensinya sangat terbatas, materi tersebut terbilang sangat banyak. Mahasiswa menganggap bahwa perlu adanya bahan ajar tambahan yang dapat membantu menambah referensi khususnya mata kuliah Botani Tumbuhan Tinggi materi Angiospermae kelas Liliopsida yang di lengkapi dengan integrasi keislaman. Karena sering menggunakan referensi jurnal yang belum spesifik, masih ada beberapa mahasiswa yang kurang antusias dalam mempelajari materi pada mata kuliah Botani Tumbuhan Tinggi sehingga penguasaan konsep terbilang rendah dan kurang baik. Hal ini dibuktikan dengan hasil belajar mahasiswa yang memiliki presentase 52,38\% mendapatkan nilai $\mathrm{C}$ dari 21 mahasiswa yang mengambil mata kuliah Botani Tumbuhan Tinggi pada angkatan tahun 2013. Persentase tersebut terbilang rendah karena setengah dari jumlah mahasiswa masih kurang dalam penguasaan materi yang telah disampaikan. Ketersediaan buku yang tidak sesuai dengan RPS dari dosen pengampu mata kuliah Botani, membuat mahasiswa kurang tepat dalam menafsirkan materi yang telah di cantumkan. Kurangnya referensi juga sangat mempengaruhi pemahaman dalam belajar atau memenuhi tugas yang digunakan sebagai bahan penilaian dosen terhadap hasil belajar mahasiswa.

Uraian tersebut mendasari perlunya sebuah penelitian pengembangan modul mata kuliah Botani Tumbuhan Tinggi khususnya materi Angiospermae kelas Liliopsida. Sehingga dirasa perlu adanya penelitian pengembangan modul yang terintegrasi keislaman pada mata kuliah Botani Tumbuhan Tinggi. Hasil penelitian ini akan digunakan sebagai dasar pertimbangan pengembangan modul pembelajaran sehingga menambah referensi bagi mahasiswa. Untuk itulah perlu dilakukan penelitian dengan judul Pengembangan Modul Pembelajaran Terintegrasi Keislaman Mata Kuliah Botani Tumbuhan Tinggi Materi Angiospermae kelas Liliopsida.

Penelitian Benny ( 2016 ) dengan judul pengembangan modul IPA berbasis integrasi Islam dan sains untuk meningkatkan hasil belajar pada siswa kelas VI MIN Seduri Mojokerto. Penelitian ini menghasilkan bahan ajar berupa modul pembelajaran IPA kelas VI. Penelitian ini relevan karena samasama penelitian pengembangan yang menghasilkan produk berupa modul yang terintegrasi keislaman. Pengembangan ini dikembangkan dengan model ADDIE (Analyse, Design, Development, Implementation, Evaluation). Hasil dari pengembangan ini berupa spesifikasi produk berupa modul pembelajaran IPA berbasis integrasi Islam dan Sains. Penelitian ini dianggap relevan karena memiliki tingkat keefektivitasan, kemenarikan, kelayakan yang tinggi dan sudah sesuai dengan kebutuhan pengguna. Hal ini dibuktikan dari hasil validasi ahli materi tingkat kelayakan kelayakan $87 \%$, validasi ahli media tingkat kelayakan $86 \%$, validasi ahli bahasa tingkat kelayakan $78 \%$, validasi ahli pembelajaran tingkat kelayakan 94\%. Hasil uji lapangan 
terhadap siswa kelas VI MIN Seduri Mojokerto menunjukkan bahwa tingkat efektivitas yang tinggi. Sementara perbedaan dari penelitian milik Benny dengan yang akan dikembangkan adalah subjek penelitian, dimana Benny menggunakan subjek penelitian siswa MIN dan yang akan dikembangkan menggunakan subjek penelitian yaitu mahasiswa. Produk yang dihasilkanpun berbeda, penelitian yang akan dikembangkan menghasilkan produk modul pembelajaran pada materi Angiospermae kelas Liliopsida.

\section{METODE}

Penelitian ini merupakan penelitian dan pengembangan (research and development). Penelitian pengembangan digunakan untuk mendesain produk atau prosedur baru yang teruji secara sistematis di lapangan, dievaluasi, di kembangkan sedemikian rupa sehingga memenuhi kriteria efektivitas, kualitas atau kemiripan dengan suatu standard model ADDIE yang dikemukakan oleh Russel dan Mollenda (1993) berisi silabus, rencana pelaksanaan pembelajaran, kegiatan pembelajarn, evaluasi, kunci jawaban, petunjuk penilaian evaluasi, rubrik penilaian sikap dan keterampilan.

Model ADDIE terdiri dari lima tahapan, yaitu tahap analisis (analyse), tahap perencanaan (design), tahap pengembangan (development), tahap pelaksanaan (implementation), dan tahap evaluasi (evaluation). Subyek yang diteliti yaitu pengguna modul pembelajaran terintegrasi keislaman mata kuliah Botani Tumbuhan Tinggi materi Angiospermae kelas Liliopsida, sedangkan subyek yang dikembangkan yaitu modul pembelajaran terintegrasi keislaman mata kuliah Botani
Tumbuhan Tinggi materi Angiospermae kelas Liliopsida.

Instrumen pengumpulan data pada penelitian yaitu instrumen tes, angket, dan lembar observasi. Tes digunakan untuk memperoleh data keterampilan berpikir kritis siswa dengan menggunakan metode pretest dan postest. Kemudian pengisian angket untuk memperoleh data analisis kebutuhan, analisis kinerja dan data sikap. Sedangkan lembar observasi digunakan sebagai konfirmasi kesesuaian data yang diberikan mahasiswa dari pengisian angket sikap.

\section{HASIL DAN PEMBAHASAN}

Hasil penelitian yaitu produk utama berupa modul pembelajaran terintegrasi keislaman mata kuliah Botani Tumbuhan Tinggi materi Angiospermae kelas Liliopsida. Model pengembangan yang digunakan yaitu ADDIE yang dikemukakan oleh Russel dan Mollenda (1993). Hasil penelitian dan pembahasan sebagai berikut.

Tahap awal yaitu analisis disusun skenario pengembangan dan spesifikasi produk yang dikembangkan. Disusun pula kisi-kisi angket untuk menganalisiskebutuhan mahasiswa, kebutuhan mahasiswa, dan disusun lembar observasi. Analisis dilakukan analisa pada kebutuhan mahasiswa dan kebutuhan dosen. Tahap ini juga dilakukan wawancara kepada mahasiswa dan dosen mata kuliah Botani Tumbuhan Tinggi. Hasil wawancara mahasiswa diperoleh suatu kesimpulan bahwa mahasiswa belum menggunakan bahan ajar berupa modul pembelajaran untuk proses berlangsungnya pembelajaran.

Tahapan kedua yaitu desain. Pemilihan metode, bahan ajar. Setelah melakukan tahap analisis, tahap selanjutnya 
yaitu mendesign atau merancang produk. Langkah yang dilakukan dalam mendesain produk modul pembelajaran terintegrasi Keislaman mata kuliah Botani Tumbuhan Tinggi materi Angiospermae kelas Liliopsida ini diantaranya adalah menyesuaikan kegiatan belajar dengan RPS yang sudah disediakan oleh dosen pengampu mata kuliah Botani Tumbuhan Tinggi. Modul di desain dengan menggunakan kertas HVS putih, dengan ukuran kertas B5, spasi huruf 1,5, ukuran font 12 dan jenis huruf Arial (LKPP UNHAS, 2015 dan Rahdiyata, 2016).

Adapun penyajian modul disusun berdasarkan urutan sampul (cover), kata pengantar, daftar isi, peta konsep, pendahuluan (petunjuk penggunaan modul, capaian pembelajaran dan indikator capaian pembelajaran), kegiatan belajar, tes formatif (evaluasi), glosarium, daftar pustaka, kunci jawaban dan biografi (Direktorat Tenaga Kependidikan, 2008 dan Hernawan, 2012).
Setelah usai melakukan design langkah selanjutnya yaitu development atau pengembangan. Pengembangan disini yaitu proses pencetakan produk yang kemudian siap untuk dilakukan proses validasi. Validasi produk modul pembelajaran terintegrasi keislaman mata kuliah Botani Tumbuhan Tinggi materi angiospermae kelas liliopsida diuji oleh 4 orang ahli yang terdiri dari 2 orang ahli materi, 1 orang ahli agama (integrasi Keislaman) dan 1 orang ahli media (desain). Kriteria penentuan subyek ahli yakni berpengalaman di bidangnya dan berstatus sebagai dosen.Instrument validasi menggunakan skala likert 4 skala.Adapun hasil validasi ahli dijabarkan sebagai berikut.

\section{Hasil Validasi Ahli Materi}

Materi dalam produk ini dinilai oleh 2 orang ahli materi (2 orang dosen ) Tadris Biologi IAIN Palangka Raya. Adapun hasil data validasi materi dapat dilihat pada Tabel.1.

Tabel.1. Hasil Validasi Ahli Materi

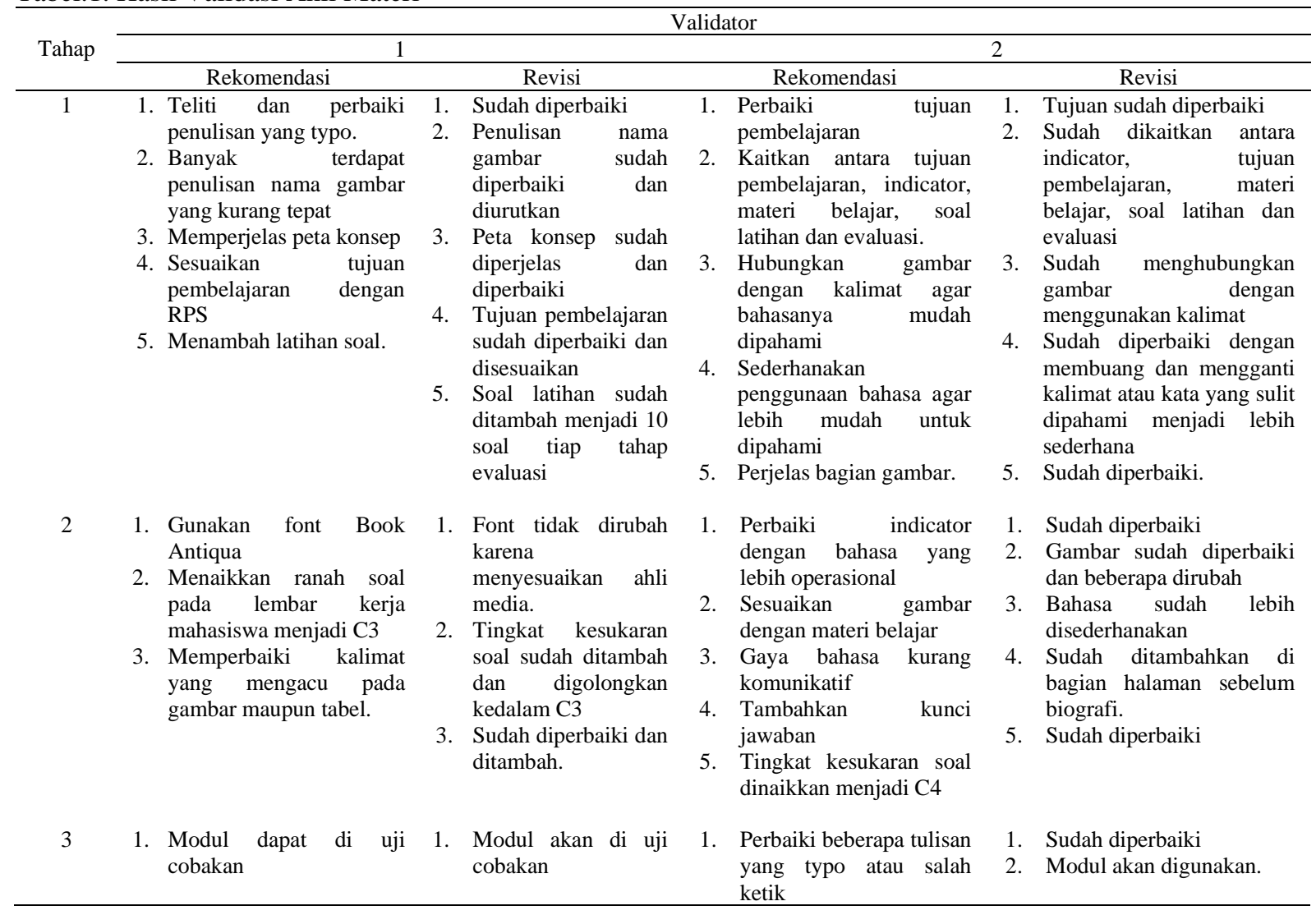




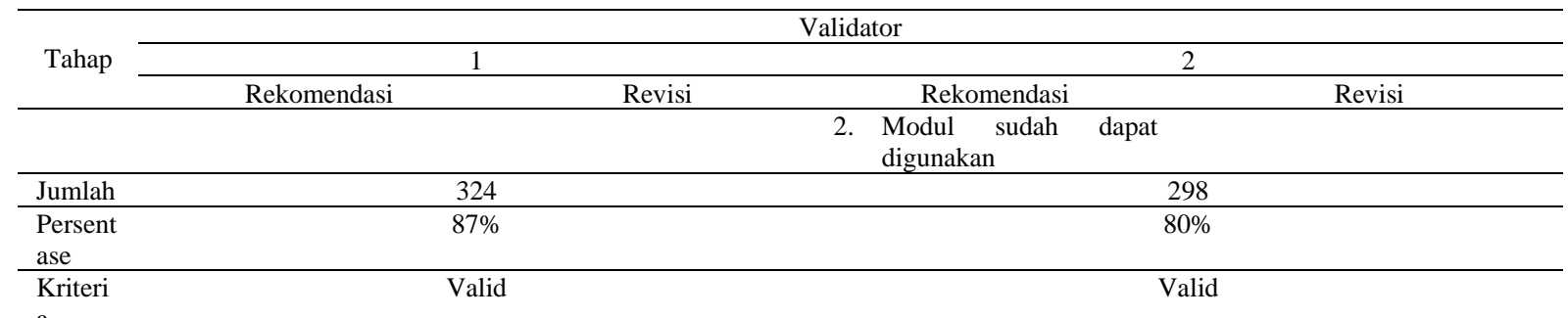

Berdasarkan Tabel 1. bahwa proses validasi bagian isi (materi) dinyatakan masuk dalam kriteria Valid atau dinyatakan valid dan dapat di uji cobakan atau digunakan pada tahap selanjutnya. Hasil validasi ahli materi dapat dilihat secara rinci

Hasil Validasi Ahli Agama (Integrasi Keislaman)

Tabel 2. Hasil Validasi Ahli Agama (Integrasi Keislaman) 2.

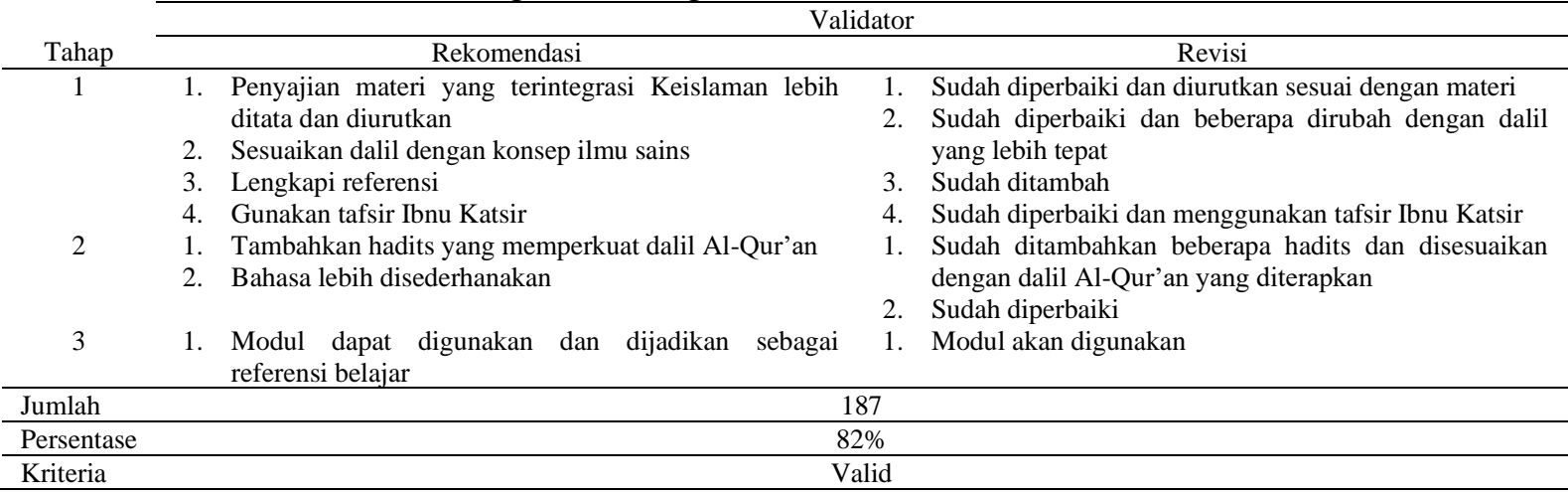

Berdasarkan Tabel 2. diatas, hasil validasi agama (Integrasi Keislaman) yang dilakukan oleh 1 orang ahli yaitu dosen tafsir di Tadris Biologi IAIN Palangka Raya menyatakan bahwa termasuk dalam kriteria valid dan dapat digunakan ke tahap selanjutnya.

Tabel 3. Hasil Validasi Ahli Media (Design)

\section{Validasi ahli agama (integrasi} Keislaman) bertujuan untuk mengkaji kesesuaian hubungan antara poko bahasan dengan ayat-ayat Al-Qur'an yang telah dikembangkan. Validator ahli agama (integrasi Keislama) yakni 1 orang merupakan dosen tafsir di IAIN Palangka Raya. Hasil validasi dapat dilihat pada Tabel

\section{Hasil Validasi Ahli Media (Desain)}

Validasi ahmi media bertujuan untuk mengatur kemenarikan dari penyajian produk yang dikembangkan. Adapun ahli media atau design terdiri atas satu orang dosen mata kuliah Teknologi Informasi di IAIN Palangka Raya.Hasil validasi ahli media dapat dilihat pada Tabel 3.

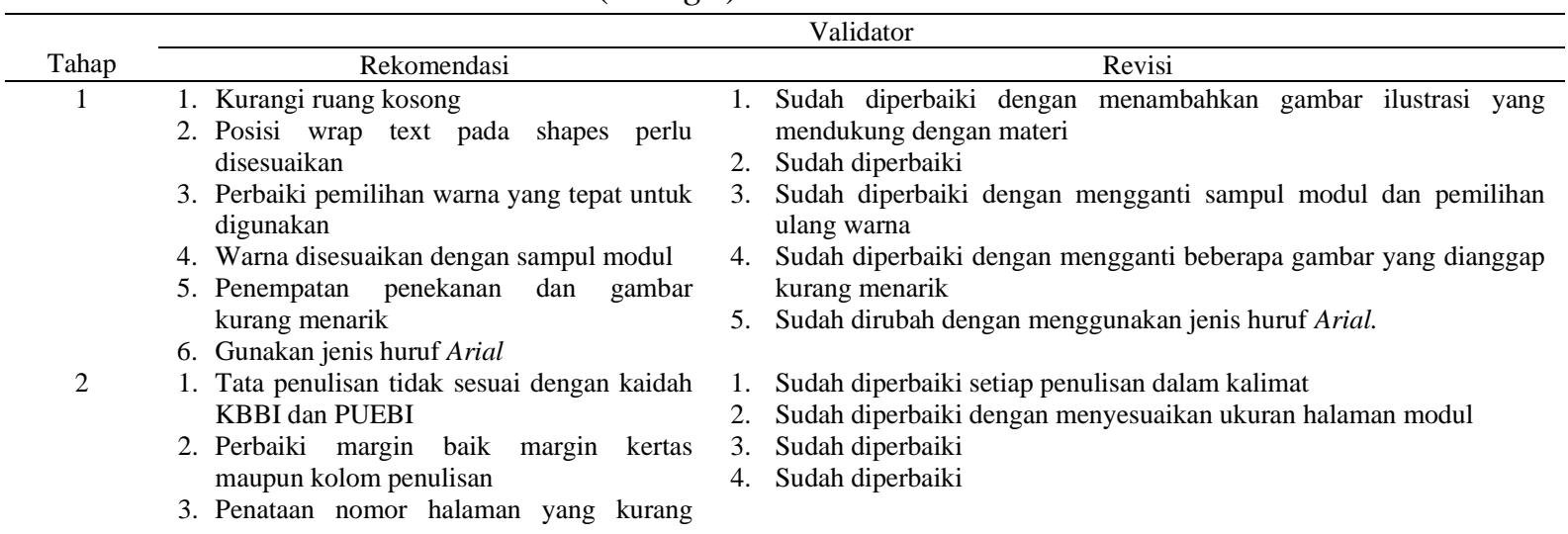




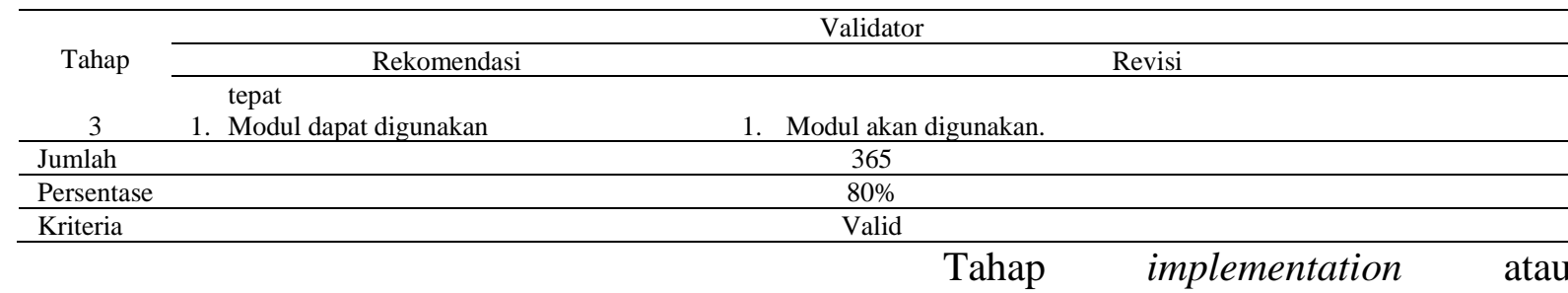

Berdasarkan Tabel .3. diatas, hasil implementasi dilakukan setelah tahap revisi validasi tahap 1, 2 dan 3 oleh ahli media dari 1 validator (dosen mata kuliah Teknologi Informasi di IAIN Palangka Raya ) termasuk ke dalam kategori valid dan dapat digunakan pada tahap penelitian selanjutnya. Setelah desain produk dan melakukan validasi dengan validator ahli materi, agama dan media langkah selanjutnya yaitu melakukan revisi produk (modul) yang dikembangkan berdasarkan masukan-masukan dari para ahli selama beberapa tahapan. Hasil validasi ahli oleh pakar terhadap modul pembelajaran terintegrasi keislaman mata kuliah botani tumbuhan tinggi materi angiospermae kelas liliopsida sesuai dengan hasil validasi ahli oleh Sulastri, Wiharti, \& Nugroho (2019); Hartini, Hanik \& Nugroho (2019); Nugroho \& Subiyantoro (2017).

Setelah produk usai di validasi oleh ahli/pakar serta revisi/perbaikan, produk (modul) selanjutnya di uji coba kan pada mahasiswa dengan skala kecil yang berperan hanya sebagai simulasi, uji coba skala kecil lebih mengacu untuk menilai kemenarikan isi produk dan peningkatan hasil belajar dengan ranah yang sedikit. Sebagai proses simulasi penelitian, uji coba skala kecil diberikan perlakuan yaitu sebelum belajar menggunakan modul mahasiswa melaksanakan pretest untuk mengukur kemampuan mahasiswa sebelum diberikan produk (modul), selanjutnya setelah menggunakan produk (modul) mahasiswa melaksanakan posttest untuk mengetahui peningkatan hasil belajar mahasiswa setelah diberi perlakuan. melakukan uji coba skala besar.Uji coba skala besar terdiri dari 2 kelas yaitu kelas kontrol yang terdiri dari 13 mahasiswa (mahasiswa kelas B) dan kelas eksperimen yang terdiri dari 13 mahasiswa (mahasiswa kelas A).berikut perincian data dari masingmasing kelas.

Peningkatan hasil belajar mahasiswa tanpa menggunakan modul dilihat dari nilai pretets dan postest masing-masing mahasiswa mengalami peningkatan, namun peningkatan tersebut tidak signifikan karena masih berada di bawah dari nilai KKM mata kuliah Botani Tumbuhan Tinggi yang ditetapkan.

Kelas eksperimen merupakan kelas yang diberikan perlakuan dengan jumlah mahasiswa sebanyak 13 orang. Kelas eksperimen diberi perlakuan yakni dengan belajar menggunakan modul pembelajaran terintegrasi Keislaman mata kuliah Botani Tumbuhan Tinggi materi angiospermae kelasliliopsida. Sebelum belajar, mahasiswa melakukan pretest dan diakhiri dengan postest. Berikut penjelasan mengenai pelaksanaan penelitian pada kelas eksperimen.Hasil belajar kelas eksperimen melebihi KKM mata kuliah Botani Tumbuhan Tinggi yang sudah ditetapkan. Data nilai pretest dan postest kelas eksperimen dapat dilihat pada Tabel 4. 
Tabel 4. Data nilai pretest dan postest kelas eksperimen

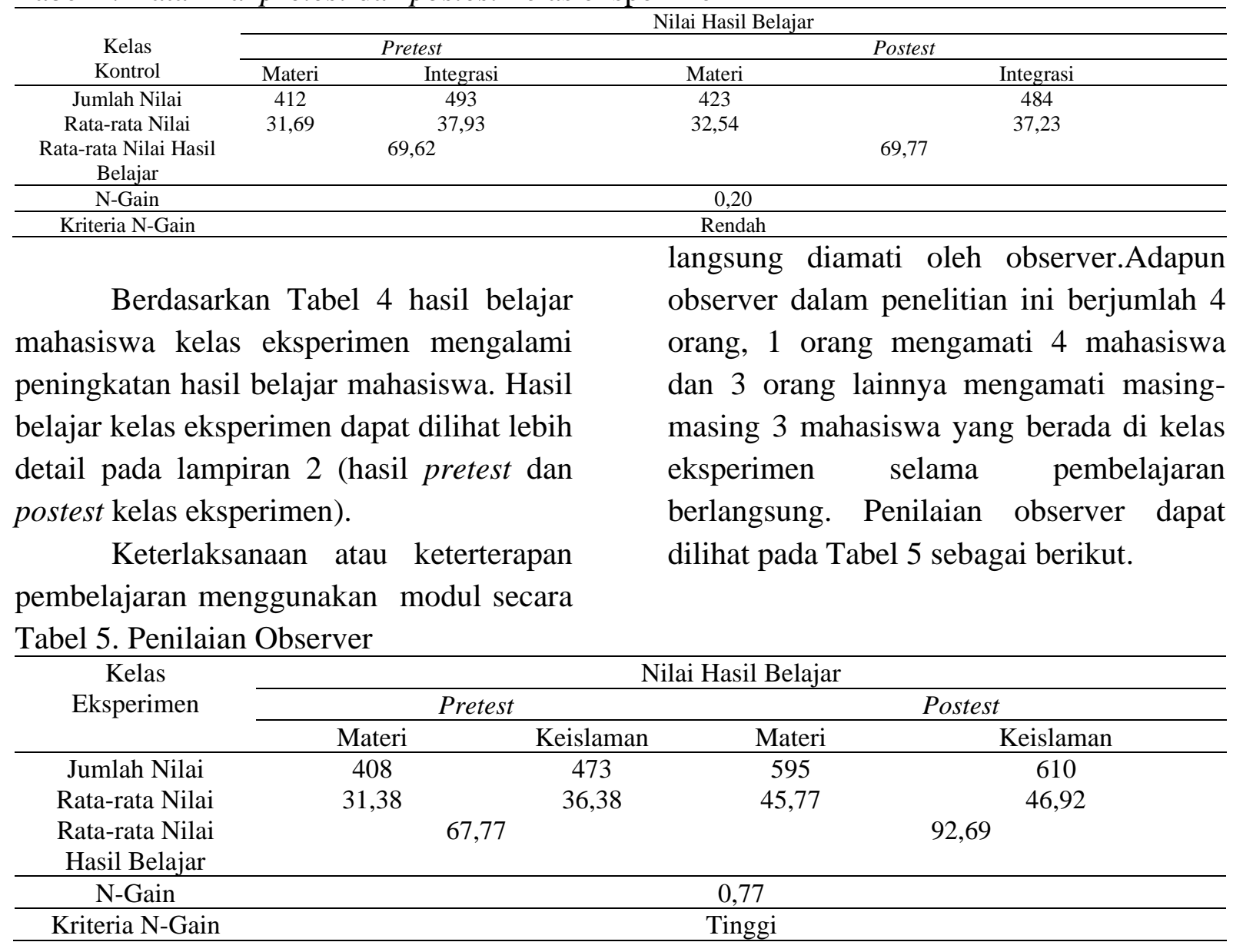


Berdasarkan keterangan pada Tabel 5. diatas, keterterapan modul pembelajaran terintegrasi keislaman memperoleh persentase skor 99,15 \% dengan kriteria sangat berhasil, sehingga modul dapat dikatakan layak untuk digunakan dalam pembelajaran mata kuliah Botani Tumbuhan Tinggi.

Evaluation (Evaluasi).Tahap evaluasi merupakan tahap revisi terakhir terhadap modul (produk yang dikembangkan). Perbaikan atau evaluasi yang dilakukan yaitu berdasarkan pada masukan yang diperoleh dari angket respon atau catatan lapangan pada lembar observasi. Tujuan dari iniyaitu agar modul (produk yang dikembangkan) benar-benar sesuai serta dapat digunakan pada mata kuliah Botani Tumbuhan Tinggi.

\section{SIMPULAN DAN SARAN}

\section{Kesimpulan}

Modul pembelajaran terintegrasi keislaman mata kuliah Botani Tumbuhan Tinggi materi Angiospermae kelas Liliopsida yaitu dengan menggunakan desain ADDIE dengan langkah utama adalah analisis kebutuhan, dilanjutkan dengan desain pengembangan sampai dalam bentuk prototipe, dilanjutkan dengan development (pengembangan) berawal dari proses validasi hingga proses simulasi (uji skala kecil), dilanjutkan dengan implementasi (penerapan) yaitu pengambilan data pada kelas kontrol dan eksperimen, dan berakhir pada proses evaluasi hingga produk final.

$$
\text { Profil modul pembelajaran }
$$

terintegrasi keislaman mata kuliah Botani Tumbuhan Tinggi materi angiospermae kelas liliopsida yaitu sampul, kata pengantar, peta konsep, pendahuluan, daftar isi, kegiatan belajar, glorasium, daftar pustaka dan dilengkapi dengan kunci jawaban yang dicantumkan pada modul yang digunakan sebagai pegangan dosen.

Modul pembelajaran dinyatakan valid oleh ahli materi karena sudah mencakup materi yang sesuai dengan capaian pembelajaran, dan sesuai dengan kurikulum yang sudah ditetapkan. Modul dinyatakan valid oleh ahli keagamaan karena isi materi modul sudah sesuai dengan nilai-nilai Keislaman di dalam Al-Qur'an dan dilengkapi dengan hadits-hadits yang mendukung dengan kesesuaian materi dengan integrasi. Modul dikatakan valid oleh ahli media/design karena modul yang dikembangkan sudah mencakup aspek media meliputi kejelasan dalam menggunakan modul seperti yang tertera pada petunjuk penggunaan modul, keterbacaan teks/huruf, kualitas tampilan gambar, kemenarikan gambar, dan kontras warna yang sesuai.

Modul dinyatakan efektif dilihat dari peningkatan hasil belajar yakni rata-rata nilai pretest dan postest pada kelas eksperimen. Modul dinyatakan praktis yaitu berdasarkan dari penilaian keterlaksanaan belajar yang diamati secara langsung oleh observer yaitu dengan kriteria sangat baik karena mahasiswa terlihat aktif dan antusias dalam belajar. Modul juga dinyatakan praktis berdasarkan respon baik dari mahasiswa ditinjau dari tingkat kemudahan mahasiswa dalam menggunakan modul selama proses pembelajaran.

\section{Saran}

Berdasarkan hasil penelitian dan pembahasan diatas, saran dari peneliti yaitu 1) Modul pembelajaran terintegrasi keislaman mata kuliah Botani Tumbuhan Tinggi materi angiospermae kelas liliopsida dikembangkan dengan menggunakan model pengembangan ADDIE sehingga perlu 


\section{Journal of Biology Learning}

Volume 2, Issue 1, page 23 - 32, March 2020

adanya pengembangan bahan ajar lain yang lebih spesifik agar dapat membantu proses berlangsungnya pembelajaran mata materi lain, 2) Pembelajaran menggunakan modul sebaiknya digunakan juga untuk materi biologi yang lainnya sehinga mahasiswa tertarik, senang, tidak menjadi bosan dalam mengikuti kegiatan belajar biologi.

\section{UCAPAN TERIMA KASIH}

Penulis mengucapkan terima kasih kepada semua pihak sehingga penelitian dan penulisan artikel ini dapat berjalan dengan lancar.

\section{DAFTAR PUSTAKA}

Daryanto \& Aris D. C. (2014). Pengembangan Perangkat Belajar. Yogyakarta : Gava Media.

Daryanto, (2013). Menyusun Modul Bahan Ajar Untuk Persiapan Guru dalam Belajar. Yogyakarta : Gava Media.

Devi\& Apriska A. (2014). Pengembangan Multimedia Interaktif Elektrolit untuk Pembelajaran Kimia Siswa SMK Kelas XI Jurusan Pertanian Tahun Pelajaran 2013/2014."Jurnal Pendidikan Kimia,4 (2).

Donald, A. (1982). Introduction to Research in Education Terj. Arif Furqon. Surabaya : Usaha Nasional.

Hartini, H., Hanik, N. R., \& Nugroho, A. A. (2019). Keanekaragaman dan Kemelimpahan Serangga di Hutan Bromo Karangannyar Sebagai Sumber Alternatif Belajar Biologi di SMA. Journal of Biology Learning, 1(1).

Nugroho, A. A., \& Subiyantoro, S. (2017). Pengembangan Modul Sistematika Tumbuhan Tinggi Berbasis Guided Discovery untuk Mengembangkan Kemampuan Berpikir Kritis Mahasiswa Pendidikan Biologi. BIOPEDAGOGI, 6(2), 19-24.

Permadi, B. A. (2016). Pengembangan Modul IPA Berbasis Integrasi Islam dan Sains Untuk Meningkatkan Hasil Belajar pada Siswa. Malang : UIN Maulana Malik Ibrahim.

Putri, D. S. (2016). Pengembangan modul berorientasi unity of sciences dengan pendekatan contextual teaching and learning pada materi Termokimia (Doctoral dissertation, UIN Walisongo).

Puspitasari, A \& Rakhmawati, L. (2013). Pengembangan e-Book Interaktif pada Mata
Kuliah Elektronika Digital. Jurnal Pendidikan Teknik Elektro, 2(2).

Pratiwi, Mardiah. (2017). Pengembangan Tutorial Pembuatan Media Aquascape Berbasis Project Based Learning (PjBL) Pada Materi Ekosistem Siswa Kelas X SMA. Lampung : UIN Raden Intan.

Pribadi, B. A. (2009). Model Desain Sistem Pembelajaran. Jakarta : Dian Rakyat.

Rahdiyanta, D. (2016). Teknik Penyusunan Modul. Artikel.Yogyakarta : Universitas Negeri Yogyakarta Press.

Rianto, Adi. (1997). Metodologi penelitian.Yogyakarta: Pustaka.

Sulastri, S., Wiharti, T., \& Nugroho, A. A. (2019). Keanekaragaman Tumbuhan Paku di Kawasan Wisata Alam Candi Muncar Wonogiri Sebagai Bahan Penyusunan Modul Pembelajaran. Journal of Biology Learning, 1(1).

Yunita N. (2010). Pengembangan Modul. Surakarta : Universitas Negeri Sebelas Maret. 